\title{
Heidelberg, Spinoza and Academic Freedom
}

\section{From a Correspondent}

IN connexion with the forthcoming celebration 1 of the 550th anniversary of the University of Heidelberg, it is of interest to note that the date for this, namely June 27-30, has been significantly chosen. June 30 is the anniversary of that series of events in 1933, now known familiarly as the 'clean up', which established the full rigour of the new regime in Germany. Any visitor to Heidelberg at that date will therefore be able to celebrate both events.

An event of a different kind may be remembered on February 16, which is the anniversary of an important historic gesture by the University of Heidelberg. On February 16, 1673, a letter was sent from Heidelberg to the philosopher Spinoza inviting him to occupy a chair as 'Ordinarius' in that university. This appears to have been the first occasion on which a university called to a professorship one who was known not to profess its prevailing religion. The opinions of Spinoza were at that date widely known. The relevant parts of the letter of invitation may be translated as follows :

"To the Very Acute and Renowned Philosopher, Benedict de Spinoza

Most renowned Sir,

His Serene Highness the Elector Palatine, my most Gracious Master, has commanded me to write to you, who are yet unknown to me, but most highly commended to His Serene Highness the Prince, and to ask you whether you are willing to accept an Ordinary Professorship of Philosophy in his Illustrious University. . . . You will not find anywhere a Prince more favourable to distinguished geniuses, among whom he reckons you. You will have the utmost freedom of philosophizing, which he believes you will not misuse to disturb the publicly established Religion."

There follow a few compliments and directions and the letter ends:

"I will add only this, that if you come here, you will live pleasantly a life worthy of a Philosopher. So Farewell and Hail to you, most honoured Sir,

From your most devoted,

\section{J. LOUIS FABRITIUS,}

Professor in the University of Heidelberg, Heidelberg, 16 February 1673."

It is just ten years since the definitive edition of the works of Spinoza was published by the University of Heidelberg. Had Spinoza himself been living to-day, it would be quite impossible for him to occupy a position at Heidelberg. That university has dismissed or forced into retirement more than forty-five of its staff on the ground either of their opinions or of their Jewish descent. Spinoza would have come under the ban on both these counts. Nevertheless, Heidelberg is deeply indebted to men who have had a similar history to Spinoza. Emil Lask, a thinker of Jewish origin, was perhaps the most important philosopher that Heidelberg has produced for half a century. He was, moreover, the only member of the Philosophical Faculty of Heidelberg who fell in the War. Yet it was in the very building where Lask had held his seminars that there appeared in 1933 the well known notice of the Deutsche Studentenschaft: Wenn der Jude Deutsch screibt, lügt er. ("When a Jew writes the German language, he is lying.") No member of the Faculty protested.

On the façade of one of the great university edifices at Heidelberg-built largely by the help of benefactors of Jewish origin-there stands the inscription Dem Lebendigen GeIst (To the Living Spirit). The new regime does not approve this formula and the discussion still rages as to whether it should not be changed to Dem DEUTSCHEN GEIST!

It is an indication of the atmosphere in which teaching is now carried on in Germany that the distinguished physicist, Philipp Lenard of Heidelberg, has just issued the first of the four volumes of his great treatise on physics with the title "Deutsche Physik". It bears a dedication to Dr. Frick, Minister of the Interior, "dem Förderer grosser Forschung im Dritten Reich"! and the opening sentences of the preface may be translated thus :

"'German Physies ?', one asks. I might rather have said Aryan Physies or the Physies of the Nordic Species of Man (der nordisch gearteten Menschen), the Physics of those who have fathomed the depths of Reality, seekers after Truth, the Physics of the very founders of Science. But I shall be answered 'Science is and remains international'. It is false. Science, like every other human product, is racial and conditioned by blood."

In connexion with these changes in the atmosphere of the German universities, it may be recalled that one of the founders of modern science, the first to adumbrate the doctrine of the 
conservation of matter, a philosophical predecessor of Spinoza, the great liberal Cardinal Nicolaus Cusanus, was a student at Heidelberg and wrote the famous "De pace fidei". It is sometimes said that Germany has returned to the Middle Ages. Would that she had returned to the Middle Ages as represented by the Cardinal who is perhaps the greatest of the children of the University of
Heidelberg. The Heidelberg Academy is or was in the course of publishing the works of Cusanus. This has not prevented the authorities at Heidel. berg from acting in a spirit utterly opposed to that of Cusanus, and unseemly incidents, prompted by dem deutschen Geist, are occurring even in connexion with the issue of the works of Heidelberg's illustrious son.

\section{Obituary}

\section{Prof. J. H. Ashworth, F.R.S.}

$\mathbf{J}^{\mathrm{A}}$ AMES HARTLEY ASHWORTH was born in Accrington, brought up in Bolton, Lancashire, and educated at Owen's College, Manchester. It was his intention to specialise in chemistry, but he transferred to zoology. He was trained under A. Milnes Marshall and C. H. Hurst and later under S. J. Hickson, all outstanding zoologists and excellent teachers. His marked ability soon became apparent, for he obtained the Dalton prize in natural history, graduated B.Se. of London at the age of twenty-one years, and four years later obtained the D.Se. of the same University. From 1896 until 1900 he held the post of junior lecturer and demonstrator in zoology at Manchester. He then spent some time at the Biological Station at Naples, and the large amount of material he collected there is evidence of his zeal and enthusiasm. The visit impressed him deeply, and he retained an affection for the Station and the zoologists he met there. Until his death he was chairman and secretary for the British Association table at Naples. He was for many years the recorder of Section D (Zoology) of the Association and was president of the Section in 1923.

In 1901 Ashworth was appointed lecturer in invertebrate zoology at Edinburgh. Four years later the University instituted a diploma in tropical medicine, and such was the trust reposed in him that he was asked by the medical faculty to conduct a course in entomology and parasitology for this diploma. This was no easy task, since it was the first course of its kind to be given in Britain. $\mathrm{He}$ threw himself wholeheartedly into the work and brought to bear on it his extensive knowledge of invertebrate zoology, his teaching skill and his interest in the relationship between zoology and medicine. The course achieved conspicuous success, and from the beginning set a high standard which it has since maintained. His title now became lecturer in medical entomology and parasitology. Later, helminthology was added to the course, which was modified to furnish the basis of instruction for the diploma in public health and the diploma in tropical veterinary medicine. Students who attended these classes have come from, and are to be found in, all parts of the world. It must have been gratifying to Ashworth that so many of his former students came to visit him when on leave and kept in touch with him by correspondence. A number of them presented specimens, often illustrative of their own special lines of investigation, so that he built up an excep. tionally complete teaching collection. All of this testifies to the affectionate gratitude that he inspired in his students.

In spite of heavy teaching duties, Ashworth pub. lished a number of important researches. The earlier ones were concerned with coelenterates and marine worms, but the later included Protozoa and helminths. These papers are characterised by meticulous care and accuracy of observation, by clear and concise exposition, and are illustrated by drawings showing more than ordinary skill. The paper on "The Habits and Structure of Arenicola marina" (Quart. J. Micro. Sci., 1898), written conjointly with F. W. Gamble, was the precursor of a series of publications on Polychætes, including the memoir on Arenicola in the Liverpool Marine Biological Com. mittee Series, which is used in zoological laboratories throughout the world. He became the recognised authority on his group and was asked to write the catalogue of the Chætopoda in the British Museum, A, Pt. I, Arenicolidæ. His work on the group was by no means confined to systematics but included noteworthy contributions to anatomy and histology, particularly the paper on "The Giant Nerve Cells and Fibres of Halla parthenopeia" (Phil. Trans. Roy. Soc., 1909). His eminence in research led to his election to the Royal Society of Edinburgh in 1911 (of which he was general secretary when he died), to the Royal Society of London in 1917, and to the award of the Keith medal of the former Society in 1916.

Ashworth early realised that the accommodation and arrangements for the teaching of zoology in the University were hopelessly inadequate, and when in 1919 he was made professor of zoology, he saw the opportunity for remedying this state of affairs. He set before himself two aims and devoted himself steadfastly to their accomplishment. They were the building up of a staff, laboratories and equipment suitable for giving a satisfactory course in general zoology, and secondly, increasing the usefulness and raising the standard of the classes in zoology for medical students, both undergraduate and graduate, 